\title{
SOME REMARKS ON THE TURKICISATION OF THE MONGOLS IN POST-MONGOL CENTRAL ASIA AND THE QIPCHAQ STEPPE
}

\author{
JOO-YUP LEE \\ Oxford Centre for Islamic Studies \\ Marston Road, Oxford, OX3 0EE, U.K. \\ e-mail: jooyup.lee@utoronto.ca
}

The Turkic nomads of the Mongol successor states in Central Asia and the Qipchaq Steppe arose from the merging of various Turkic groups and the Mongols. The former had consisted of heterogeneous elements that did not coalesce into a single entity sharing a common identity and historical consciousness. They thus did not constitute a uniform majority in relation to the more cohesive Mongols. In terms of tribal and genetic compositions, the Turkic nomads of the Mongol successor states were closer to the Mongols than to the pre-Mongol Turkic groups. Naturally, they held on to a predominantly Mongol orientation rather than reverting to pre-Mongol identities.

Key words: Turkic nomads, Mongol Empire, Mongol descendants, Turkicisation, Mongolness, Y-DNA haplogroup, Central Asia, Qipchaq Steppe.

\section{Introduction}

By the late 14th century, the Mongol descendants in Central Asia and the Qipchaq Steppe, including the members of the Chinggisid dynasty and such tribes of Mongol origin as the Barlas, Manghit, and Qunghrat, had become speakers of Turkic languages. Historians accordingly remark that these Mongol descendants were "Turkicised" and refer to them as "Turks" or "Turkicised Mongols". ${ }^{1}$ However, we hear of no Turkic amīrs or tribal leaders of the Mongol successor states ${ }^{2}$ in Central Asia and

${ }^{1}$ For instance, Peter Golden (2011, pp. 93-94) refers to the nomads of Moghulistan or the eastern Chaghatayid khanate as "Turks" and "Turkicised Mongols".

${ }^{2}$ The Mongol successor states in this paper refer to the polities whose ruling elites consisted of the Mongol descendants and honoured the Mongol political traditions. They include the Timurid Empire, Moghul Khanate, Uzbek Khanate, Kazakh Khanate, Crimean Khanate, Mughal Empire, and Northern Yuan, among others. 
the Qipchaq Steppe seeking to revive the pre-Mongol Turkic states or looking to the latter for political legitimation during the post-Mongol period. ${ }^{3}$ The Turkic nomad elites of the Mongol successor states instead continued to honour the charisma and traditions of the Mongol Empire. ${ }^{4}$ Most notably, Temür, the Turkic-speaking Muslim conqueror who created a vast empire encompassing the western half of the former Mongol Empire, proclaimed himself heir to the Mongol Empire, ${ }^{5}$ not to the ancient Kök Türk Khagahanate or the pre-Mongol Muslim Turkic dynasties such as the Seljuqs or the Qarakhanids.

We may then wonder why the Turkic nomads ${ }^{6}$ of the Mongol successor states in Central Asia and the Qipchaq Steppe did not exhibit some sort of pre-Mongol Turkic identity. As a matter of fact, it has been remarked by V. V. Bartol'd (1962, pp. 5-6; 1964, pp. 203-204) that "while the Mongols were being Turkicised in the West, the Turks themselves gradually absorbed the traditions of Chingiz-khan's empire, until the reminiscences of the Turkish rulers of pre-Mongol times came to be obliterated". Although I essentially agree with Barthold's remarks, I do not consider his explanation to be comprehensive. I would like to point out that the Turkic groups of Central Asia and the Qipchaq Steppe also forgot about their pre-Islamic past before

\footnotetext{
${ }^{3}$ In the Mongol successor states, there was no such thing as "ethnic conflict" (or "class struggle") between the Turkic nomads of indigenous origin and the nomad elites of Mongol origin (or "the Mongol feudal overlords") as some pan-Turkic historians or the Soviet historians would like us to believe. Such a point of view is well reflected in the following quote from a work following Kazakh scholarship: "The collapse of Mongolian authority after 1395, released the hunger of the indigenous people for self-determination ... the gradual recovery from the Mongol conquest saw the growing influence of the local Turkic nobles and intensified the people's resistance to the feudal powers of the Mongol Khans ..." (Fergus-Jandosova 2003, p. 121). However, no such occurrences of "ethnic conflict" or "class struggle" are attested to in Central Asian sources. As will be discussed below, there was no clear line of distinction between the indigenous Turkic elements and the Mongol elements among the Turkic nomads of the Mongol successor states in Central Asia and the Qipchaq Steppe.

${ }^{4}$ The Mongol orientation of the Turkic nomad elites in post-Mongol Central Asia and the Qipchaq Steppe has been noted and discussed by Beatrice F. Manz (1989, pp. 1-12; 1994, pp. $5-7)$.

${ }^{5}$ By contemporaries, Temür was often depicted as a Mongol. For instance, the $M u$ ' $i z z$ alansāb fi shajarat al-ansāb, a Timurid genealogy of the Chinggisids and the Timurids, describes Temür as being of Mongol descent. See Mu'izz al-ansāb fi shajarat al-ansāb (2006, fol. 3a). Ibn Khaldūn (1951, p. 366) refers to Temür as "the sulțann of the Mughul and Tatar" in his work. According to Ibn 'Arabshāh (1936, p. 178; 1986, p. 320), Temür identified himself with the Qara Tatars, a Mongol group residing in Anatolia, in his letter sent to the latter. Manz (2009, p. 182) thus rightfully defines Temür as "at once Muslim, Turk and Mongol". For more on Temür's Mongol identity, see Lee (2016b, pp. 122-124).

${ }^{6}$ During the post-Mongol period, they formed such Chinggisid uluses, or nomadic peoples, as the Chaghatays (Moghuls and Timurids), Uzbeks, Qazaqs (Kazakhs), Manghits, and (Crimean) Tatars, among others.
} 
experiencing Mongol rule. ${ }^{7}$ More importantly, I question Barthold's and other historians" premise that "the majority Turks" Turkicised "the minority Mongols". 8

In this paper, I will attempt to answer the question, "Why did the Turkic nomads of the Mongol successor states in Central Asia and the Qipchaq Steppe look to the Mongol Empire for political legitimation and even retain a Mongol identity ${ }^{9}$ instead of reverting to pre-Mongol Turkic identities?" by challenging the widely held view that the Mongols were assimilated by "the majority Turks". More specifically, I will defend the following thesis: The Turkic groups of Central Asia and the Qipchaq Steppe consisted of heterogeneous elements that, in their entirety, did not coalesce into a single group identity sharing a common historical consciousness prior to being incorporated to the Mongol Empire in the 13th century. Although greater in number, they existed as separate groups and did not constitute a uniform majority in relation to the Mongols. The Turkic nomads of the Mongol successor states in Central Asia and the Qipchaq Steppe arose from the merging of these fragmented indigenous Turkic groups and the more cohesive Mongols. ${ }^{10}$ Importantly, they were closer to the 13th-century Mongols than to the pre-Mongol Oghuz or Qipchaq Turkic groups in terms of tribal and genetic compositions. As expected, they held on to a predominantly Mongol orientation rather than reverting to pre-Mongol Turkic identities. ${ }^{11}$

For this purpose, I will first demonstrate that the Turkic groups of post-Kök Türk Central Asia and the Qipchaq Steppe did not descend from a common ancestral group, drawing on the findings of DNA studies. I will highlight the fact that the various Turkic groups that were incorporated to the Mongol Empire did not constitute a homogeneous entity in terms of phenotype and patrilineal descent. Secondly, I will demonstrate that the various Turkic groups of pre-Mongol Central Asia and the Qipchaq Steppe did not share a common identity and historical consciousness. I will show that the Kök Türk identity was not widely shared by the Turkic groups of nonKök Türk descent, and that the Oghuz and Afrāsiyāb traditions were not shared by all Turkic groups. Finally, I will discuss the "Mongolness" of the Turkic nomads of the Mongol successor states in Central Asia and the Qipchaq Steppe. I will show that, in terms of tribal and genetic affiliations, they were closer to the 13th-century Mongols than to the pre-Mongol Oghuz or Qipchaq Turkic groups.

${ }^{7}$ In his unpublished online article, Ron Sela (2013) demonstrates how the new Muslim Turkic dynasties in Central Asia forgot their pre-Islamic Turkic past. Here, I would like to add that many of the "non-Muslim" Turkic groups also forgot or simply did not know about the Kök Türks.

${ }^{8}$ For instance, the Kazakh historian Tursun I. Sultanov (Klyashtornyi-Sultanov 2000, pp. 208-209) argues that the indigenous Qipchaqs Turkicised the Mongols, who were insignificant in number, to form the Kazakhs.

${ }^{9}$ For a discussion of their Mongol identity, see Lee (2016b, pp. 122-131).

${ }^{10}$ I do not use the term "Turko-Mongol" in this paper to denote the Turkic nomads of the Mongol successor states although it is widely used in scholarship. One should note that, in pre-modern Muslim sources, while Mongol was used for specific groups, that is, the Mongols or the Moghuls, Turk was often used as a generic term for Inner Asian nomads that also included the Mongols.

${ }^{11}$ I follow Manz's view that the new group identities of post-Mongol Central Asia such as the Chaghatays, Kazakhs, and Uzbeks came into being as a result of the division of Mongol identity. See Manz (1994, pp. 7-9; 2016, pp. 285-286). I dedicate this work to Professor Beatrice F. Manz whose works inspired me to become a historian of Central Asia. 


\section{The "Turks" of Pre-Mongol Central Asia and the Qipchaq Steppe: A Heterogeneous Entity}

The Turkic groups of pre-Mongol Central Asia and the Qipchaq Steppe were a heterogeneous entity in terms of phenotype and patrilineal descent. ${ }^{12}$ Unlike the Mongols, the various Turkic groups did not share common phenotypes. For instance, the Xiong-nu, the (eastern) Kök Türks and the Uighurs possessed Inner Asian phenotypic features, ${ }^{13}$ whereas some groups, most notably, the Yenisei Qirghiz had a distinct European physiognomy (see Lee-Kuang 2017, pp. 197-239). Similarly, genetic studies show that the Turkic tribes of pre-Mongol Central Asia and the Qipchaq Steppe had heterogeneous paternal origins unlike the Mongols. ${ }^{14}$ DNA testing of modern Turkic populations show that the most prevalent Y-DNA haplogroups ${ }^{15}$ among different Turkic peoples are as follows: (1) N (N1c1) among the Sakhas (Yakuts) of northeastern Siberia, who are probably descended from the Quriqan, a Tiele tribe; (2) $\mathrm{N}$ (both N1b and N1c1) and C2 among the Tuvinians of the Sayan Mountains region, who are probably descended from the Tiele and/or the Kök Türks; (3) R1a1 and C2 among the Qirghiz (Kyrgyz) of the Tien Shan Mountains, who are probably descended from the ancient Qirghiz; (4) N and R1a1 among the Khakass of the Yenisei River region, whose name was created by the Soviets from Xiajiasi (黠戛斯), a Chinese name for the ancient Qirghiz; (5) R1a1, N, and J among the Turkic peoples of the Volga-Ural region, who are descended from various groups; (6) R1a1, J, and $\mathrm{O} 2$ or $\mathrm{C} 2$ among the Xinjiang Uighurs and the Uzbeks (of the Central Asian oasis regions called East and West Turkestan in the past), who are descended from various Turkic and Indo-European groups; (7) C2, O2, and G1 among the Kazakhs, who are descended from various Turkic tribes and the Mongols; (8) Q, J, and R1a1 among the Turkmens, who are descended from the Oghuz; (9) J, R (R1a1 or R1b), E, and G2 among the Turks and the Azeris of Anatolia and the Caucasus region, who are descended from various Turkic and indigenous groups (see Lee-Kuang 2017, pp.

${ }^{12}$ I am not concerned with modern theories of ethnicity or identity in this study. Also, I shall not discuss the definition of Turk here. My main concern is to demonstrate the heterogeneity of the Turkic-speaking groups of pre-Mongol Central Asia and the Qipchaq Steppe in terms of patrilineal descent, self-identity, and historical consciousness.

${ }^{13}$ According to Russian anthropologists, the Xiong-nu and the Kök Türks were the first to spread the "Mongoloid" phenotype beyond Mongolia. See Oshanin (1964, Vol. 2, p. 20); Ismagulov (1968, pp. 130-131).

${ }^{14}$ Unlike the various Turkic peoples, the modern-day Mongols are characterised by the high frequency of a single Y-DNA clan, which is haplogroup C2. For the Mongol genetic makeup, see Katoh et al. (2005, p. 66).

${ }^{15}$ A Y-DNA haplogroup is a male group that shares one or more Y-DNA mutations. When a mutation, which is a permanent structural alteration in the DNA sequence, occurs in a male person, it is passed down to all his male descendants. Over time, such mutations accumulate and this allows us to trace relatedness in groups of people. Geneticists categorise human Y-DNA into over twenty major groups. The Y Chromosome Consortium, a scholarship group organised to standardise haplogroup classification, named Y-DNA haplogroups using the capital letters A through T and their subclades using numbers and lower case letters. For the Y-DNA haplogroup nomenclature, see ISOGG (2018). 
210-222). What these DNA data tell us is that modern Turkic populations do not descend from a common ancestral group and that the same may hold true for the Turkic groups of pre-Mongol Central Asia and the Qipchaq Steppe.

The Y-chromosomes of the Kök Türk elites, who cremated their dead (Wei Zheng 2008, Chapter 84, p. 1864), have not been investigated yet. We can only presume their patrilineal lineages by testing the DNA of their direct descendants, who are, however, difficult to identify. The Zhoushu [the book of the Zhou Dynasty] (Linghu Defen 2003, Chapter 50, p. 908) informs us that the Ashina, the royal clan of the Kök Türks, were related to the Qirghiz. If so, the Ashina may have belonged to the R1a1 lineage like the modern-day Tienshan Qirghiz, who are characterised by the high frequency of R1a1 (over 60\%). ${ }^{16}$ Haplogroup R1a1, more specifically, its subclade R1a1a1b2 defined by mutation Z93, was carried by the Indo-European pastoralists, who reached the Kazakh steppes, the Tarim Basin, the Altai Mountains region, the Yenisei River region, and western Mongolia from the Black Sea steppes during the Bronze Age (Semino et al. 2000, p. 1156). ${ }^{17}$ The Chinese histories also inform us that one of the three tribes of the Muma Tujue (木馬突厥) [Wooden-horse Türk] was Doubo, who are probably the ancestors of the Tuvinians. ${ }^{18}$ If the modern descendants of the Kök Türks are Tuvinians, who are characterised by moderate to high frequencies of haplogroups N (42.2 45.1\%), C2 (16.1 26.5\%), and Q (4.9 13.9\%), the Kök Türks may have carried haplogroups N, C2 and Q, among others (see Table 3 in Gubina et al. 2013, p. 339; Kharkov et al. 2013, p. 1239). ${ }^{19}$ Haplogroup N originated in East Asia and spread from Siberia into eastern/northern Europe approximately eight to ten thousand years ago (Shi et al. 2013, pp. 1-9). Haplogroup C2 is the major lineage of the Mongols, Kazakhs, and Evenks, who are speakers of the proposed Altaic language family. ${ }^{20}$ Haplogroup $Q$ is found at varying frequencies among some Turkic peoples, two Siberian peoples (Yeniseinan Kets and Uralic Selkups at 93.7\% and 66.4\%, respectively) (see Table 3 in Tambets et al. 2004, p. 667), and the Native Americans (at over 90\%) (Dulik et al. 2012, pp. 229-246).

When compared to the Kök Türks, the genetic structure of the ancient Uighurs/Tiele is easier to identify since it may be inferred from the DNA testings of their descendants, namely, the Sakhas, the Western Yugurs, the Naiman tribe among the Kazakhs, and the Buryats, among others. The Sakhas (Yakuts), who probably descended from the Quriqan (Tokarev 1962, p. 107), a Tiele tribe, are characterised

${ }^{16}$ See Table 1 in Wells et al. (2001, p. 10245) where M17 corresponds to haplogroup R1a1.

${ }^{17} \mathrm{M} 17$ or Eu19 in this article corresponds to R1a1; Keyser et al. (2009, pp. 406-409); Li et al. (2010, pp. $9-10)$.

${ }^{18}$ For the Muma Tujue, see Xin Tangshu (Ouyang Xiu-Song Qi 2003, Chapter 217b, p. 6148). Denis Sinor (1985, pp. 152-157) suggests that the Muma Tujue were the Kök Türks "living outside the Türk state" or "[not belonging] to the ruling stratum of the Türk state".

${ }^{19} \mathrm{C} 3$ in these articles correspond to $\mathrm{C} 2$.

${ }^{20}$ For the Evenks, see Table 5 in Pakendorf et al. (2007, p. 1017). C-M217 and its subclades C-M48 and C-M86 correspond to C2. For the Mongols and Kazakhs, see Table 1 in Wells et al. (2001, p. 10245). M130 and M48 in Table 1 corresponds to haplogroup C2; and see Table 3 in Zerjal et al. (2002, p. 474). Haplogroups 10 and 36 in Table 3 correspond to haplogroup C2. 
by haplogroup N1c1. ${ }^{21}$ The Western Yugurs, residing in Gansu Province, China, are descended from the remnants of the ancient Uighurs (Golden 1992, p. 409) and are characterised by moderate to high frequencies of haplogroups $\mathrm{C} 2(21.2 \sim 30 \%), \mathrm{O} 2$ (34.6\%), and Q (15\%) (see Figure 2 in Zhou et al. 2008, p. 202; Xu-Wen 2017, p. 69). Haplogroup $\mathrm{O} 2$ (formerly known as O3) is the genetic marker of East Asians (see Table 1 in Xue et al. 2005, pp. 2431-2439), also found among various Mongolic and Turkic groups at moderate frequency. The Naiman, a Turkic tribe subdued by Chinggis Khan in the early 13th century, are now found among the modern-day Kazakhs and are characterised by high frequencies of haplogroups $\mathrm{O} 2$ and $\mathrm{C} 2{ }^{22}$ The Buryats, who, at least partly, descend from the Quriqan (Tokarev 1962, p. 107; Golden 1992, pp. 106-107), like the Sakhas, are characterised by high frequencies of haplogroups $\mathrm{N}(48 \%)$ and C2 (40\%) (see Table 1 in Kharkov et al. 2014, p. 183). In sum, the Tiele/ancient Uighurs were probably carriers of haplogroups $\mathrm{C} 2, \mathrm{~N}, \mathrm{O} 2$, and Q, among others.

We may also infer the genetic structure of the Yenisei Qirghiz, who destroyed the Uighur Khaganate in $840 \mathrm{CE}$, from that of their modern descendants. The Qirghiz (Kyrgyz) of the Tien Shan Mountains region (in Kyrgyzstan) ${ }^{23}$ are characterised by moderate to high frequency of R1al (over 60\%) and C2 (12 20\%). ${ }^{24}$ The Khakass, who are also believed to have descended from the Yenisei Qirghiz, are characterised by high percentages of $\mathrm{N}(50 \%)$ and R1al $(35.2 \%){ }^{25}$

We may speculate on the genetic structure of the Qipchaqs based on the DNA of their modern descendants among the Kazakhs. The Qipchaq (Karakypshak) tribe belonging to the Kazakh Middle Horde (Orta Jüz) is characterised by a high frequency of R1b1a1a1 (R1b-M73) (Sabitov 2013, p. 35). R1b1a1a1 is a rare haplogroup that appears at moderate to high frequency only among this Kazakh tribe and some other Turkic groups (including the Kumandin). ${ }^{26}$ We may also speculate that the modern descendants of the Qipchaqs are the western Kazakhs, who are characterised by a high frequency of C2 subclade C2b1b1 (formerly known as C3c1). ${ }^{27}$

We are unable to identify the genetic structure of the Qarakhanids, who were made up of the Qarluq and Chuyue tribes, among others. ${ }^{28}$ Recently, Chinese geneticists tested the DNA of the remains of a Yuan nobleman, who was probably an

${ }^{21}$ Most of the Y-chromosome DNA extracted from the mummified frozen bodies of the Sakhas dating from the 15th to the 19th centuries belongs to haplogroup N1c1 (61\%). See Crubézy et al. (2010, p. 2).

${ }^{22}$ For haplogroup C2, see Table S1 in Zhabagin et al. (2017, pp. 1-11). For haplogroup O, see Sabitov (2013, p. 35).

${ }^{23}$ On their descent from the Yenisei Qirghiz, see Golden (1992, pp. 404-406).

${ }^{24}$ See Table 1 in Wells et al. (2001, p. 10245) where M17 corresponds to haplogroup R1a1; and Table 3 in Zerjal et al. (2002, p. 474). Haplogroups 3, 10, and 36 in Table 3 correspond to haplogroups R1a1, C2, and C2b1b1, respectively.

${ }^{25}$ See Table 3 in Gubina et al. (2013, p. 339); and Table S3 in Shi et al. (2013, pp. 1-9). Haplogroup $\mathrm{N}$ found among the Khakass may have originated in the Turkic nomads who Turkicised the R1a1 carriers.

${ }^{26}$ For the Kumandin, see Table 2 in Dulik et al. (2012, p. 234).

${ }^{27}$ For the haplogroups of the western Kazakh tribes, see Sabitov (2013, p. 35).

${ }^{28}$ For the tribal composition of the Qarakhanids, see Golden (2015, pp. 509-510). 
Önggüt prince. This nobleman's Y-DNA haplogroup was Q (Cui et al. 2015, pp. 3, 5-8). One should note that the Önggüt may have descended from the Chuyue. The Yuanshi [the history of the Yuan Dynasty] (Song Lian 2005, Chapter 118, p. 2923) states that the chief of the Önggüt, Alawusi Tijihuli (阿刺元思剔吉忽裏), who submitted to Chinggis Khan in 1203, was "a descendant of the Shatuo-yanmen (沙陀 雁門之後)”. In turn, the Xin Tangshu (Chapter 218, p. 6153) relates that the Shatuo (沙陀) were “a sort of the Chuyue, a separate tribe of the Western Tujue (西突厥別 部處月種也)”. Furthermore, the Qarluq (Geluolu 歌邏祿) and the Chuyue (處月) belonged to the Western Türk tribal union. ${ }^{29}$ In sum, we may conjecture that the Y-DNA haplogroups of the Qarakhanids included those of the Kök Türks and those of the indigenous tribes of the Qipchaq Steppe.

The genetic structure of the mediaeval Turkmens or Oghuz, from whom the Seljuqs and the Ottomans branched off, are easier to identify since it is not difficult to identify their modern descendants. The major Y-chromosome haplogroups of the modern-day Turkmens are haplogroups Q, R1a1, J and N, among others. The Y-DNA haplogroups of the Turkmens living in Afghanistan and northern Iran are as follows: $\mathrm{Q}(33.8 \sim 42.6 \%), \mathrm{J}(14.3 \sim 17.6 \%)$, R1a1 $(14.5 \sim 16.2 \%), \mathrm{L}(4 \sim 5.8 \%),{ }^{30} \mathrm{G}(4 \sim 5.7 \%), \mathrm{N}$ and $\mathrm{O}(2.9 \sim 9.45 \%), \mathrm{E}(4.3 \sim 5.4 \%)$, and $\mathrm{C}(0 \sim 1.35 \%){ }^{31}$ Among the Turkmens living in Uzbekistan (Karakalpakstan), mostly belonging to the Yomud tribe, haplogroups Q (73\%) dominates the gene pool (Skhalyakho et al. 2016, p. 88), which indicates that haplogroup Q was probably the most prevalent lineage among the Oghuz.

In sum, in terms of patrilineal descent, the Turkic groups of pre-Mongol Central Asia and the Qipchaq Steppe did not, in all likelihood, descend from a common ancestral group. Although the genetic makeup of the Kök Türks is yet to be identified by geneticists, one cannot observe a common set of Y-DNA haplogroups that could have been spread by them or by any other common ancestral group among the various Turkic groups. ${ }^{32}$ It is also highly likely that many of the mediaeval Turkic

${ }^{29}$ The Jiu Tangshu (Chapter 194b, p. 5179) lists the Qarluq and Chuyue among the tribes of the Western Türks.

${ }^{30}$ Haplogroup L is a South Asian lineage, found at significant frequencies in South Asia, but at low frequencies in the Middle East, Europe and Central Asia. For its frequency in India and elsewhere, see Tables 5, 6, and 7 in Sengupta et al. (2006, pp. 202-221). $1-12)$.

${ }^{31}$ See Table 1 in Grugni et al. (2012, p. 7); Figure S7 in Di Cristofaro et al. (2013, pp.

${ }^{32}$ Concerning the genetic structure of the earliest Turkic peoples, one may assume that their lineages included haplogroups N, C, Q, and R1a1, among others. R1al (its subclade R1a-Z93) is found at high frequencies among the Turkic peoples of the Altai Mountains and Tienshan Mountains regions. Rlal could have been one of the most prevalent lineages among the Turkic groups of the Qipchaq Steppe after the Turkicisation of this region. However, it is unlikely that the earliest Turkic speakers were characterised by a high frequency of haplogroup R1a1 since the earliest carriers of this haplogroup in South Siberia and Central Asia were Indo-European speakers. It was the carriers of haplogroup R1a1 that spread the Indo-European languages to South Asia and Iran. Haplogroup Q is found at varying frequencies among several historical Turkic peoples such as the Turkmens, Önggüt, and Western Yugurs, which makes it an important candidate for one of the original Turkic lineages. However, the presence of haplogroup Q is minimal among many other Turkic peoples including the Kazakhs and the Qirghiz (Kyrgyz). If haplogroup Q was indeed one of 
groups were non-Turkic by origin. These facts are attested to by their diverse representative haplogroups and dissimilar haplogroup compositions. It was thus natural that the Turkic groups of pre-Mongol Central Asia and the Qipchaq Steppe, made up of heterogeneous elements, did not create and share a common identity or historical consciousness as will be discussed below.

\section{The Absence of a Common Identity in the Pre-Mongol Turkic World}

The various Turkic groups of pre-Mongol Central Asia and the Qipchaq Steppe did not share a common identity. To begin with, they did not share a common "Kök Türk" identity, which had existed as a group identity reserved for the core group of the Türk Khaganates. One should note that the Kök Türks did not regard other Turkic groups as Türks. For instance, the Kök Türks did not use the name Türk for other Turkic-speaking groups such as the Toquz Oghuz (Tiele) and Qirghiz in the Orkhon inscriptions. ${ }^{33}$ Similarly, the Uighurs, who succeeded the Kök Türks in Mongolia in the mid-8th century CE, did not identify themselves as Türks. The Uighurs called themselves Uighur (Uyzur) and used the name Türk (Türük) only for the Kök Türks, whom they depicted as their enemies, in their royal inscriptions. ${ }^{34}$

The "Kök Türk" identity, however, may have been preserved among the direct descendants of the Kök Türks. The Khazars, who probably branched off from the Western Türks, ${ }^{35}$ may have claimed descent from the Ashina. ${ }^{36}$ According to Peter

the original Turkic lineages, one may observe that the genetic legacy of the original Turks is rather minimal. Haplogroup $\mathrm{N}$ is commonly found among most Turkic peoples. It is the dominant lineage of the Siberian Turkic peoples such as the Tuvinians, the Khakass, the (Oghur Turkic) Chuvash, and the Saka (of Quriqan/Tiele descent), who are perhaps more homogeneous than the Turkic peoples of Central Asia and West Asia. Haplogroup C is the most common lineage of the Mongolic and Tungusic peoples. However, it is also found at a high frequency among many Turkic groups including the Kazakhs, the Tuvinians, the Western Yugurs (of Uighur/Tiele descent), and the Naiman tribe. Its high frequency among these Turkic groups indicates that it was carried by the Turkic groups of western Mongolia prior to the rise of the Mongols. Haplogroup C was also present in Mongolia during the Xiongnu period. For now, it would be safe to say that the early Turkic peoples included haplogroups $\mathrm{N}, \mathrm{C}, \mathrm{Q}$, and R1a1, like the Xiongnu.

${ }^{33}$ See the lines 11-14 (east side) of the Kül Tegin inscription translated in Silay (1996, p. 4).

${ }^{34}$ For instance, the Taryat (Terkhin) inscription records that the Uighur khan El Etmiš Bilgä said the following: "At my age of twenty-eight, in the Year of the Serpent, I disturbed and destroyed the realm of the Turk." (see Tekin 1983, p. 46 [text], p. 49 [trans.]). The Moyun Čor (ŠineUsu) inscription also records El Etmiš Bilgä's words as follows: "I heard that Özmiš Tegin had become qan (of the Türüks). In the Sheep Year (A.D. 743), I marched (with my army) ... I seized (Özmiš Qayan) ... Thereafter the Türük people has ceased to exist" (see the lines 9-10 [north side] of the Šine-Usu inscription, Moriyasu et al. 2009, p. 11 [text], p. 24 [trans.]).

${ }^{35}$ They are referred to as Tujue Hesa 突婑曷薩 (Türk Khazar) in the Xin Tangshu (Chapter 221b, p. 6247).

${ }^{36}$ However, the mid-10-century Khazar ruler Joseph claimed descent from Khazar, the seventh son of Togarmah, a son of Japheth in his letter to Hasdai b. Shaprūt, the Jewish courtier of the Caliph of Cordoba. He was thus following the biblical tradition, not the Ashina or Kök Türk 
Golden, the Hudūd al-'älam records that the Khazar ruler descends from Ansā, that is, Ashina (see Golden 2013, p. 53). The same may hold true for the Qarluq (Geluolu 歌邏祿), the Chuyue (處月), ${ }^{37}$ and the Türgesh (Tuqishi 突騎施) ${ }^{38}$ that had belonged to the Western Türk tribal confederation centred in the Kazakh steppes. In his Dīwān Luḡāt at-Turk, the Qarakhanid philologist Mạ̣mūd Al-Kāšğarī (fl. c. 1075) uses the name Turk only for the Qarakhanids, made up of the former Western Türk tribes Qarluq and the Chuyue (Chigil), among others, when he uses Turk in a narrow sense. ${ }^{39}$ However, it is not clear if the Qarakhanids possessed a "Kök Türk" identity. When describing the Ötükän mountains, the homeland of the Kök Türks, AlKăšgarī simply writes that it is the "name of a place in the deserts of Tatār, near Uighur", without mentioning the Kök Türks (Al-Kāšgarī 1982-1985, Vol. 1, p. 159). One should note that the Qocho Uighurs, who were descended from the Uighur refugees who settled in the Tarim Basin after the collapse of the Uighur Khaganate (744-840 CE), were aware that their place of origin was the Orkhon River valley (see Juvayn̄̄ 1958, Vol. 1, p. 54). As a matter of fact, Al-Kāšğarī does not mention the Ashina or the Kök Türks in his work. It seems that he did not have any real memory of the Kök Türks. ${ }^{40}$ Concerning the progenitors of the Turkic groups, Al-Kāšgarī mentions Turk, son of Japheth, son of Noah (Al-Kāšgarī 19821985, Vol. 1, p. 82), and Alp Er Tonga, whom, like Yūsuf Khāṣṣ Haajib, the author of the Kutadgu Bilig, he identifies with Afrāsiyāb, the Turanian hero of the Shāh-nāma (Al-Kāšğarī 1982-1985, Vol. 2, p. 337; Yūsuf Khāṣṣ Hājib 1983, p. 48), ${ }^{41}$ without mentioning any historical Kök Türk figure.

All in all, it appears that, by the turn of the second millennium CE, the memory of the Kök Türks and the Ashina clan had been obliterated in the Turkic world. Various Turkic groups created their respective dynastic traditions or foundation myths that were unrelated to the Ashina legend and the Kök Türks.

The Qocho Uighurs developed a founding legend, according to which the progenitor of their state was born of a tree. ${ }^{42}$

tradition, in accordance with the conversion of the Khazar elite to Judaism (see Zhivkov 2013, p. 41).

${ }^{37}$ As mentioned above, the Jiu Tangshu lists the Qarluq and Chuyue among the tribes of the Western Türks (Jiu Tangshu Chapter 194b, p. 5179 in Liu Xu 2002).

${ }^{38}$ For instance, in the Jiu Tangshu (Chapter 194b, p. 5190), Wuzhilei (烏質勒), a Türgesh chief, is described as being from “a separate stock of the Western Türks (西突厥之別種)”.

${ }^{39}$ Al-Kāšğarī also uses Turk in a broader sense to refer to the Inner Asian nomadic groups in general (see Al-Kāšğarī 1982-1985, Vol. 1, p. 83).

${ }^{40}$ On this point, see Golden (2015, p. 507).

${ }^{41}$ For a discussion of this identification, see Vásáry (2015, pp. 19-20). Perhaps, Alp Er Tonga was a legendary hero of the Qarluq and the Chuyue (Chigil).

42 “一夕, 有天光降於樹, 在兩河之間, 國人即而候之.樹生㾦, 若人娃身然. 自是光恆見 者越九月又十日, 而瘎裂, 得嬰兒五, 收養之. 其最稺者, 曰卜古可罕.” See Yu Ji 㲊集 (1965, Vol. 2, p. 259); 'Alā' al-Dīn 'Ațā Malik Juvaynī (1958, Vol. 1, pp. 55-56) also relates in his work that the legendary founder of the Uighurs, Bügü Khan, whom he identifies with Afrāsiyāb, was born of two parent-trees. According to the Moghul historian Muhammad Haidar Dughlat (1996, p. 184; 2004, p. 418), the Moghuls identified Bügü Khan (Būghā Khan) with Afrāsiyāb. 
One evening, a heavenly light shone down upon a tree that was between two rivers. The people of the realm drew near and waited. The tree yielded a lump that looked like a person pregnant. This light was continuously visible for nine months and ten days, and then the lump broke. [The people] received five babies whom they adopted and raised. The youngest among [the babies] was called Bügü Qaghan.

The (Yenisei) Qirghiz, who destroyed the Uighur Khaganate in $840 \mathrm{CE}$, probably had a founding legend that was not related to the Kök Türk origin myths. The You yang za zu, written by Duan Chengshi in the 9th century CE, relates that the Qirghiz viewed themselves as descending from a god and a cow. ${ }^{43}$

The Jiankun (堅昆) [Qirghiz] tribe, [unlike the Türks], is not of wolf descent. Their ancestors were born in a cave located to the north of the Quman Mountain. They themselves say that in the ancient times there was a god who mated with a cow in that cave. The people's hair is yellow, eyes are green, and beards are red.

Like the Qarakhanids, the Seljuqs did not possess any memory of the Kök Türks and the Ashina clan (Mecit 2014, p. 4). They may have considered Oghuz Khan, the legendary ancestor of the Oghuz Turkic tribes, to be their progenitor. However, the Oghuz tradition ${ }^{44}$ did not preserve any memory of the Kök Türks. Besides, it was probably not regarded as an important source of legitimation by the Seljuqs. ${ }^{45}$ According to A.C.S. Peacock, the early Seljuqs may have used the Khazar connection to legitimise themselves rather than emphasise their Oghuz origin. ${ }^{46}$ Some Seljuq court historians also saw Afrāsiyāb, the Turanian hero of the Shāh-nāma, as the ancestor of the Seljuqs. For instance, Ibn Hassūl (d. 1058) connected the Seljuqs to Afrāsīyāb (Kafesoğlu 1972, p. 5). ${ }^{47}$ However, according to Songül Mecit (2014, p. 2), it is not clear if the Seljuq rulers actually viewed themselves as the descendants of Afrāsiyāb. ${ }^{48}$

As a matter of fact, neither the Oghuz tradition nor the Afrāsiyāb tradition was widely shared by the Turkic groups in pre-Mongol Central Asia and the Qipchaq

43 “堅昆部落非狼種，其先所生之窟在曲漫山北。自謂上代有神與牸牛交於此窟. 其人 髮黃, 目綠, 赤髭髡.” Duan (n.d., Chapter 4).

For the legend of Oghuz Khan, see Rashīd al-Dīn (1988, pp. 29-45; 1998-1999, Vol. 1, pp. 27-35). For an English translation of the Oghuz tradition written in Uighur script and preserved in the Bibliothèque Nationale de France in Paris (MS Supplément turc 1001), see Doğruyol (2012, pp. 187-196). For a study of the Oghuz tradition, see Bınbaş (2010).

45 It was the Ottomans, the Aqqoyunlu and the Qaraqoyunlu who legitimised their dynasty through the adoption of the Oghuz tradition. On this point, see Peacock (2010, p. 59). In contrast, the Timurids chose the Mongol tradition. On this, Manz (2016, pp. 288-289) remarks that the postMongol Turkic dynasties of the Middle East were divided into two distinct groups, with their respective descent myth. In her work, Manz also views the Oghuz tradition as being connected with the Kök Türks. However, the present author regards the connection between the two as conjectural.

${ }^{46}$ For a detailed discussion of the Khazar connection of the Seljuqs, see Peacock (2010, pp. $27-35,59)$.

${ }^{47}$ According to Osamu Otsuka (2007, pp. 83-84), after the demise of the Seljuqs, their Afrāsiyāb descent was favoured over their Qiniq descent by the Persian historians, who sought to connect the Persian dynasties, including the Seljuqs, with the legendary Iranian heroes.

${ }^{48}$ It is also not clear if the Seljuq historians identified Afrāsiyāb with "Alp Er Tonga". 
Steppe. Importantly, Al-Kāšğarī does not associate Afrāsiyāb, whom he saw as a progenitor of the Qarakhanids, with the Seljuqs or the Oghuz in his work (Safi 2006, p. 219). He probably did not regard the Seljuqs as being related to the Qarakhanids. Furthermore, the Ghaznavids did not even adopt a steppe Turkic tradition. Unlike the Qarakhanids and Seljuqs, the Ghaznavids, who began their career as the military slaves of the Persian Samanids, sought to legitimise themselves following the Persian imperial tradition (Mecit 2014, p. 1). Their later court historians linked them to Yazdagird III, the last Sasanian ruler, discarding their steppe roots. According to István Vásáry (2015, pp. 14-17), not only the Ghaznavids, but also the Seljuqs had a strong Persian orientation. This means that the Qarakhanids, the Seljuqs, and the Ghaznavids, who formed the three most powerful Muslim Turkic states in the 11th century CE, did not share a common identity or historical consciousness. ${ }^{49}$

In sum, neither Ashina, nor Afrāsiyāb, nor Oghuz Khan served as a legitimising figure for the major portion of the Turkic world during the pre-Mongol period. The various Turkic groups of the Eurasian steppes in the pre-Mongol period did not even share a common Turkic identity ${ }^{50}$ in line with their heterogeneous origins. In contrast, the Turkic nomads of the Mongol successor states in Central Asia and the Qipchaq Steppe shared strong Mongol elements as will be discussed below.

\section{The "Mongolness" of the Turkic Nomads of the Mongol Successor States in Central Asia and the Qipchaq Steppe}

The Turkic nomads of the Mongol successor states in Central Asia and the Qipchaq Steppe arose from the merging of the above-discussed Turkic groups and the Mongols in the 13th and 14th centuries. In many respects, this hybrid group was closer to the Mongols of the 13th century than to the pre-Mongol Oghuz or Qipchaq Turkic groups.

In terms of tribal compositions, the Turkic nomads of the Mongol successor states in Central Asia and the Qipchaq Steppe, namely, the Chaghatays (Moghuls and Timurids), Kazakhs, Shibanid Uzbeks, Manghits/Noghays, and Crimean Tatars, were not made up of the "majority Turks" and "the minority Mongols". More specifically, they consisted of the tribes of Mongol origin, such as the Barlas, Barin, Dughlat,

${ }^{49}$ Interestingly, the Mamluk historian Ibn al-Dawādārī records a very unique origin myth of the Turkic peoples unrelated to the Oghuz or Afrāsiyāb tradition. According to it, the progenitor of the Turkic peoples was created in a cave from the combination of water, earth, sun, and wind (see Frenkel 2015, pp. 60-66).

${ }^{50}$ In the Islamic world, the various Turkic groups were collectively called Turks and viewed as descendants of Japheth, son of Noah. However, this Turkic identity was a broad Inner Asian identity that also encompassed the Mongols. On this point see Lee (2016b, pp. 108-113, 118122). According to Al-Kāšğarī (1982-1985, Vol. 2, p. 103), the Yaghma and the Tukhsi referred to "the Uighur infidels" as Tat, a term denoting the Iranian-speaking peoples. Also, see Vásáry (2015, pp. 13-14). Perhaps, these Uighurs were "Turkicised" local inhabitants of modern-day Xinjiang. At any rate, this is only one of the many instances that show that the pre-Mongol Turkic groups did not share a common Turkic identity. 
Manghit, Qunghrat, and Ushin; the Mongolic and Turkic tribes of non-Mongol origin, such as the Jalayir, Kereyit, Naiman, Öngüt, Tatar, and Uighur; the tribes of the Qipchaq Steppe origin, such as the Qipchaq and Qanqli; ${ }^{51}$ and other newly formed or named tribes within the Mongol polities, such as the Shirin and Ming. ${ }^{52}$ For instance, the Uzbeks of Khiva were made up of four pairs of tribes: the Kiyat-Qunghrat, UighurNaiman, Neküs-Manghit, and Qanqli-Qipchaq (see Murav'yov 1977, p. 117). The Kiyat, Qunghrat, Neküs, and Manghit were tribes of Mongol origin; the Naiman were a tribe of non-Mongol origin from Mongolia; the Qanqli and Qipchaq were indigenous tribes of the Qipchaq Steppe. The Crimean Tatar tribes included the Qipchaq, an indigenous tribe of the Qipchaq Steppe, the Shirin, a new tribe of probable Iranic origin, ${ }^{53}$ the Arghin, a tribe of obscure origin, ${ }^{54}$ and the Mansur/Manghit and Barin, tribes of Mongol origin. Here, one should bear in mind that the above-listed "nonMongol" tribes of Mongolic, Turkic, and Iranic origins were never grouped together and characterised as the "majority Turks" and contrasted with "the minority Mongols" by contemporary writers during the Mongol and post-Mongol periods.

\section{Table 1. The Tribal Composition of the Chinggisid Uluses*}

\begin{tabular}{|l|l|l|l|l|l|}
\hline & \multicolumn{1}{|c|}{$\begin{array}{c}\text { Chaghatays } \\
\text { (Timurid/Moghuls) }\end{array}$} & Kazakhs & \multicolumn{1}{|c|}{ Uzbeks } & $\begin{array}{l}\text { Crimean } \\
\text { Tatars }\end{array}$ & $\begin{array}{l}\text { Northern Yuan } \\
\text { Mongols }\end{array}$ \\
\hline $\begin{array}{l}\text { Tribes of } \\
\text { Mongol } \\
\text { origin }\end{array}$ & $\begin{array}{l}\text { Arlat, Barin, Barlas, } \\
\text { Besüd, Dughlat, } \\
\text { Qunghrat, Sudus, } \\
\text { etc. }\end{array}$ & $\begin{array}{l}\text { Dughlat, } \\
\text { Manghit, } \\
\text { Qunghrat, } \\
\text { Ushin/Uysu } \\
\text { n, etc. }\end{array}$ & $\begin{array}{l}\text { Arlat, Barin, } \\
\text { Barlas, Dur- } \\
\text { man, Man- } \\
\text { ghit, Qungh- } \\
\text { rat, Ushin/ } \\
\text { Uysun, etc. }\end{array}$ & $\begin{array}{l}\text { Barin, Ciji- } \\
\text { vut, Man- } \\
\text { ghit, etc. }\end{array}$ & $\begin{array}{l}\text { Baarin, Bayaud, } \\
\text { Besüd, Eljigin, } \\
\text { Khatagin, Man- } \\
\text { gud, Qunqirat, } \\
\text { Ushin, etc. }\end{array}$ \\
\hline $\begin{array}{l}\text { Tribes of } \\
\text { non-Mongol } \\
\text { origin from } \\
\text { the Mongo- } \\
\text { lian Steppe }\end{array}$ & Jalayir, Kereyit, etc. & $\begin{array}{l}\text { Jalayir, } \\
\text { Kereyit, } \\
\text { Merkit, } \\
\text { Naiman, } \\
\text { etc. }\end{array}$ & $\begin{array}{l}\text { Jalayir, Ke- } \\
\text { reyit, Nai- } \\
\text { man, Oirat, } \\
\text { Ongüt, Tan- } \\
\text { gut, Tatar, } \\
\text { Uighur, } \\
\text { etc. }\end{array}$ & $\begin{array}{l}\text { Jalayir, Kereyit, } \\
\text { Naiman, Öngüt } \\
\text { (Enggüd), Tan- } \\
\text { gut, Uighur, etc. }\end{array}$ \\
\end{tabular}

${ }^{51}$ Here, I follow Rashīd al-Dīn's classification of Mongol and non-Mongol tribes (see Rashīd al-Dīn 1988, pp. 21-161; 1998-1999, Vol. 1, pp. 21-112).

${ }^{52}$ For the Qazaq and Uzbek tribes, see Sultanov (1982, pp. 7-51). For the Timurid tribes, see Manz (1989, pp. 154-165); Ando (1992, pp. 66-217). For the Moghul tribes, see Mano (1978, pp. 49-52); Yudin (2001, pp. 72-82). For the Crimean Tatar tribes, see İnalc1k (1977); Fisher (1978, p. 22). 1925, p. 46).

${ }^{3}$ For the As/Alan origin of the (Crimean) Shirin tribe, see 'Abd al-Ghaffār Qïrïmī (1924-

${ }^{54}$ The Arghin (Aerhun 阿兒渾) tribe is listed as one of the semuren groups in Tao Zongyi's Nancun Chuogeng lu (1959, p. 13). However, Rashīd al-Dīn (1988) does not mention this tribe when discussing the various Inner Asian nomadic tribes in the Jämi'al-tavārīkh. 


\begin{tabular}{|l|l|l|l|l|l|}
\hline & \multicolumn{1}{|c|}{$\begin{array}{c}\text { Chaghatays } \\
\text { (Timurid/Moghuls) }\end{array}$} & Kazakhs & \multicolumn{1}{|c|}{ Uzbeks } & $\begin{array}{l}\text { Crimean } \\
\text { Tatars }\end{array}$ & $\begin{array}{l}\text { Northern Yuan } \\
\text { Mongols }\end{array}$ \\
\hline $\begin{array}{l}\text { Indigenous } \\
\text { tribes of the } \\
\text { Qipchaq } \\
\text { Steppe }\end{array}$ & $\begin{array}{l}\text { Qangli, Qipchaq, } \\
\text { etc. }\end{array}$ & $\begin{array}{l}\text { Qangli, } \\
\text { Qipchaq, } \\
\text { etc. }\end{array}$ & $\begin{array}{l}\text { Qangli, } \\
\text { Qipchaq, } \\
\text { etc. }\end{array}$ & $\begin{array}{l}\text { Qipchaq, } \\
\text { etc. }\end{array}$ & $\begin{array}{l}\text { Asud (Alan), } \\
\text { Kharachin } \\
\text { (partly Qip- } \\
\text { chaq), etc. }\end{array}$ \\
\hline $\begin{array}{l}\text { Newly or- } \\
\text { ganised or } \\
\text { named } \\
\text { tribes }\end{array}$ & Yasa'uri, etc. & $\begin{array}{l}\text { Shapyrash- } \\
\text { ty, Baiuly, } \\
\text { etc. }\end{array}$ & Ming, etc. & $\begin{array}{l}\text { Shirin } \\
\text { (As/Alan), } \\
\text { etc. }\end{array}$ & $\begin{array}{l}\text { Khalkha, Tu- } \\
\text { med, etc. }\end{array}$ \\
\hline
\end{tabular}

${ }^{*}$ This table is not exhaustive.

If we are to choose the most representative descendants of the Turkic nomads of the Mongol successor states in Central Asia and the Qipchaq Steppe, our choice must fall on the Kazakhs since they are descended from the nomads of the eastern wing of the Jochid Ulus (the Orda Ulus), the eastern Chaghatayid state (the Moghul Khanate), and the Manghit/Noghay Horde. The genetic compositions of the Turkic nomads of the Mongol successor states can thus be inferred from that of the modern Kazakhs. The most common patrilineal lineage among the Kazakhs is haplogroup C2 like among the Mongols. ${ }^{55}$ More specifically, haplogroup C2 makes up 66 73.7\% among the Kazakhs of Kazakhstan, ${ }^{56} 75.47 \%$ of the Kazakhs of Xinjiang (see Figure 1 in Zhong et al. 2010, pp. 428-435), 78\% of the Kazakhs of Karakalpakstan (see Supplementary Figure 1 in Balaresque et al. 2015, pp. 1413-1422), and 59.7\% of the Kazakhs of the Altai Republic in Russia (see Tables 1 and 2 in Dulik et al. 2011, pp. 2-3). The other Y-chromosome haplogroups that are found at low to moderate frequency among the Kazakhs are haplogroups O, G1, R1a1, R2, R1b, J, Q, and N, among others. Some of the Kazakh tribes that are divided into the Senior Horde (Ulu $J \ddot{u} z$ ), the Middle Horde (Orta Jüz), and the Lesser or Junior Horde (Kishi Jüz) have their own representative haplogroups. For instance, the Naiman, belonging to the Middle Horde, are characterised by haplogroups $\mathrm{O} 2$ and C2. ${ }^{57}$ The Arghin, another Middle Horde tribe, are characterised by haplogroup G1-M285 (Sabitov 2013, p. 35), which is believed to have originated in West Iran. ${ }^{58}$ The Qipchaq (Karakypshak),

${ }^{55}$ Haplogroup C2 found among various Turkic peoples should not be regarded as the genetic legacy of the Mongol Empire as some suggest. For instance, Zhabagin et al. (2017, pp. 5-6) argue that $\mathrm{C} 2$ found among the modern-day Uzbeks and Kazakhs was introduced to them by the Mongols. However, one should note that haplogroup C2 was carried by the Turkic tribes of Mongolia prior to the rise of the Mongols in the 13th century.

${ }^{56}$ See Table 1 in Wells et al. (2014, p. 10245) where M130 and M48 correspond to haplogroup C2; also see Table 3 in Zerjal et al. (2002, p. 474). Haplogroups 10 and 36 in Table 3 correspond to haplogroup $\mathrm{C} 2$.

${ }^{57}$ See footnote 22.

${ }^{58}$ Haplogroup G1 is mainly found in Iran and Kazakhstan. For a detailed study of haplogroup G1-M285, see Balanovsky et al. (2015, pp. 1-20). 
another Middle Horde tribe, are characterised by the R1b1a1a1 (R1b-M73) (63.6\%) (Sabitov 2013, p. 35). ${ }^{59}$

The genetic composition of the Karakalpaks, a Qipchaq Turkic-speaking people who descend from various Turkic groups and the Mongols, ${ }^{60}$ can also provide some information on the patrilineal lineages of the Turkic nomads of the Mongol successor states. They are divided into two major groups, the On Tört Uruw (that includes such tribes as the Manghit and the Qipchaq) and the Qunghrat. The Karakalpaks exhibit a set of haplogroups similar to that of the Kazakhs with a lower frequency of haplogroup C2: C2 (31.5\%), G (26\%), R1a1 (9.26\%), and N (7.4\%) among the On Tört Uruw; Rla1 (29.6\%), N (22.2\%), C2 (20.4\%), and Q (11.1\%) among the Qunghrat (see Supplementary Figure 1 in Balaresque et al. 2015, pp. $1413-1422$ ).

The modern Uzbeks exhibit a more diverse set of haplogroups than the Kazakhs: R1a1 (17.6 32\%), J (5.9 21.4\%), ${ }^{61} \mathrm{C} 2(7 \sim 18 \%), \mathrm{O} 2(0 \sim 12 \%)$, and N $\left(0 \sim 5.9 \%\right.$ ) (see Table 1 in Wells et al. 2001, p. 10245). ${ }^{62}$ However, one should differentiate between the modern Uzbeks, who are descended from the ancient IndoEuropean (Iranic) populations and various Inner Asian nomadic peoples (Golden 1992, p. 407), and the Shibanid Uzbeks who conquered Transoxiana at the turn of the 16th century and formed the nomad elite in the Uzbek Khanate. ${ }^{63}$ The Y-chromosome haplogroups of the Shibanid Uzbeks should be inferred from the DNA data of the Kazakhs since the two groups were one and the same people inhabiting the Kazakh steppes prior to their division in the 16 th century. ${ }^{64}$ Interestingly, a higher frequency of C2 (41.2\%) is observed among the Uzbeks residing in Afghanistan (Table S4 in Haber et al. 2012), who are probably descended from the Shibanid Uzbeks. ${ }^{65}$

${ }^{59}$ According to John of Plano Carpini's travel account, the majority of the Qanqli may have perished during the Mongol conquest of the Qipchaq Steppe. He writes, "The Tartars also wiped out the Kanghits and now inhabit their country; such Kangits as were left have been reduced to slavery". See John of Plano Carpini (1998, pp. 58-59). If so, the Qipchaq elements may not have constituted the majority of the nomad population of the eastern Qipchaq Steppe from the mid-13th century onwards. Alternatively, one may conjecture that Carpini was unable to distinguish the Qanqli from the Mongols.

${ }^{60}$ For the origin of the Karakalpaks, see Golden (1992, pp. 403-404). In the 16th and 17th centuries, the Karakalpaks became a semi-nomadic or semi-settled group, which indicates that they were more mixed with the sedentary populations than the nomadic Kazakhs.

${ }^{61}$ Haplogroup J reached Central Asia probably with Neolithic farmers from the Middle East (Zerjal et al. 2002, pp. 476-477). Haplogroup 9 in this paper corresponds to haplogroup J.

${ }^{62}$ M17, M130, M46, M172, M175 and 122, and M48 in Table 1 correspond to haplogroup R1a1, C2, N1c1, J, O, and C2b1b1, respectively; Table 3 in Zerjal et al. (2002, p. 474). Haplogroups $3,9,10,13,16$, and 36 in Table 3 correspond to haplogroups R1a1, J, C2, O2, N1c1, and C2b1b1, respectively; Table S4 in Haber et al. (2012).

${ }^{63}$ The modern Uzbeks can be differentiated into "joqchi Uzbeks" and "yo"kchi Uzbeks". According to Peter Finke (2014, pp. 216-219), the former have a "distinctive Mongolian" or "Kazakh" physiognomy unlike other Uzbeks.

${ }^{64}$ On their division, see Lee (2016a, pp. 121-139).

${ }^{65}$ According to Mountstuart Elphinstone (1842, Vol. 2, p. 190), the Uzbeks of the Balkh Province of Afghanistan in the 19th century were organised into tribes and possessed an Inner Asian physiognomy, which implies that they were Shibanid Uzbeks. 
From the DNA data of the Turkic peoples originating in the Mongol successor states, one may suggest that the Kazakhs, the Shibanid Uzbeks, the Manghits/Noghays, and the Crimean Tatars, who all branched off from the same Jochid Ulus, ${ }^{66}$ consisted of the following lineages: haplogroups $\mathrm{C} 2, \mathrm{O}, \mathrm{G} 1, \mathrm{Q}, \mathrm{R} 1 \mathrm{a} 1, \mathrm{R} 1 \mathrm{~b}, \mathrm{~N}, \mathrm{~J}$, and R2, among others. Here, one should note that these haplogroups or Y-DNA clans cannot be divided into the "minority Mongol" and "majority Turkic" lineages. Haplogroups such as $\mathrm{C} 2, \mathrm{~N}, \mathrm{O} 2, \mathrm{Q}$, and R1a1, among others, are shared by the Mongolic and Turkic groups, while haplogroups such as R1a1, G1, and $\mathrm{J}$ are shared by the Turkic and Iranic groups. More importantly, one cannot define or identify what constituted the "Turkic" haplogroups, since the various Turkic groups had dissimilar Y-chromosome haplogroup compositions and representative haplogroups. Furthermore, one should also note that the Turkic nomads of the Mongol successor states, characterised by haplogroup C2, were closer to the 13th-century Mongols in terms of patrilineal descent than to the Turkmens, whose major lineage was haplogroup Q, or the mediaeval Qipchaqs, whose major lineage was probably haplogroup R1bla1a1 (R1b-M73). ${ }^{67}$

Not surprisingly, the physiognomy of the Turkic nomads of the Mongol successor states in Central Asia and the Qipchaq Steppe was not very different from that of the Mongols. Sigismund von Herberstein (1963, Vol. 2, p. 53), the envoy sent to Muscovy by Emperor Maximilian I in 1517, writes about the Tatars of the Qipchaq Steppe as follows: "The men are of middle stature, with a broad, fat face, with eyes turned in and hollow, wearing no hair but the beard, shaving the rest of the hair." Guillaume Le Vasseure de Beauplan (1993, p. 41), a 17th-century French military engineer in Polish service, writes about the Crimean Tatars as follows: "They are not of great stature, their tallest men not surpassing ours of average height. They are rather shorter than taller, but are thick-set, with very big limbs; they have high and prominent bellies, broad shoulders, short necks, large heads, faces almost round, and wide foreheads. Their eyes open only a little, and are very black and wide. They have short noses, quite small mouths, teeth as white as ivory, dark complexions, and very black hair, which is coarse like horsehair." Similarlry, Charles Henry Scott (1854, p. 306), who travelled in Russia in the mid-19th century, writes about the Crimean Tatars as follows: "The Crimean Tatars are divided into two classes, those of the plain and those of the mountains ... [The former] bear on their visages the characteristics of the Mongols."

Ármin Vámbéry (1865, p. 421), the Hungarian Turkologist, who travelled in Central Asia in the mid-19th century, writes as follows about the Kazakhs: "[The

${ }^{66}$ For instance, Fażlallāh b. Rūzbihān Khunjī (1962, p. 41), the court historian of Muhammad Shībānī Khan relates in his Mihmān-nāma-i Bukhārā that there were three branches (țāyifa) that "belong to the Uzbeks" (mansūb bi-Uzbak). The first was the Shibanids (Shibānīyān). The second was the Qazaqs ( $Q a z \bar{a} q)$, "who are, in strength and ferocity, well known throughout the world" (ki dar quvva va ba's mashhūr-i äfāqand). The third was the Manghit (Manfit [sic]), "who are the rulers of Hajji Tarkhan" (ki īshān pādshāhān-i Hājjī Tarkhān-and).

${ }^{67}$ In a personal communication, Zhaxylyk Sabitov, a leading specialist in Kazakh DNA research and history, expressed the view that more than half of the mediaeval Qipchaqs belonged to R1bla1a1 (R1b-M73). 
Kazakhs] compassionate all whose faces have not the pure Mongol conformation. According to their aesthetic views, that race stands at the very zenith for beauty ..." Vámbéry depicts the Qipchaqs of Khokand, a Kazakh tribe residing in the Ferghana region, whom he views as being "the primitive original Turkish race", as follows: "In their slanting eyes, beardless chins, and prominent cheek-bones they resemble the Mongols, and are, for the most part, of small stature, but extraordinary agility" (Ibid. pp. 433-434). Similary, J. A. MacGahan (1970, p. 44), a 19th-century American journalist, writes that the Kazakhs had "small eyes, high cheek-bones, flat noses, thick lips, and round beardless faces".

As mentioned above, the Shibanid Uzbeks and the Kazakhs were one and the same people sharing the same phenotype prior to their division in the 16th century (Oshanin 1964, Vol. 1, pp. xxii-xxiii). When the Safavid ruler Tahmāsb I (r. 15141576) sent a letter to the Shibanid Uzbek khan 'Ubaidallāh (r. 1533-1540), he mocked the latter's Inner Asian physiognomy as follows: "Let your sword be tainted red by blood, O yellow-skinned man." ${ }^{, 68}$ However, over the course of time, the Shibanid Uzbeks residing in Transoxiana intermixed with the indigenous population. Therefore, Vámbéry (1865, p. 418) writes that the Uzbeks of Bukhara "have dwelt in closer connection with the Tadjiks than the Khivites have done with the Sarts, and have consequently paid the penalty by losing much of their national type ...". However, it appears that the Uzbeks of other regions better preserved their original physiognomy. Vámbéry (Ibid. p. 397) writes that a Khivan Uzbek's "complexion and form of countenance indicate very often genuine Tartar origin". Nikolay Murav'yov (1977, p. 159), a Russian visitor to Khiva in the 19th century, also recorded in his work that the Khivan Uzbeks resembled the Qalmaqs, although the former had larger eyes. Mountstuart Elphinstone (1842, Vol. 2, p. 190), a 19th-century British official in India, writes about the Uzbeks of the Balkh Province as follows: "The Uzbeks are generally short and stout men. Their national features are broad foreheads, high cheekbones, thin beards, and small eyes."

Finally, the Russian anthropologists who examined the crania of the Timurids characterised Temür as belonging to "the South Siberian Mongoloid type" ${ }^{69}$ However, they characterised his son Shāhrukh (r. 1405-1447) as belonging to "the Europeoid type" and his grandson Ulugh Beg as belonging to "the Europeoid type" with "Mongoloid admixture" (Oshanin 1964, Vol. 2, p. 39).

Unlike the Tatars, Uzbeks, and Kazakhs, the mediaeval Turkmens possessed a Tajik (Central Asian Iranian) physiognomy. Rashīd al-Dīn writes that "because of the climate their features gradually changed into those of Tajiks. Since they were not Tajiks, the Tajik peoples called them turkmān, i.e. Turk-like (Turkmānand)" (Rashīd al-Dīn 1988, pp. 35-36; Thackston 1998-1999, Vol. 1, p. 31). Abū al-Ghāzī Bahadur Khan also relates that after coming to Transoxiana, they came to have narrower chin, larger eyes, smaller faces, bigger noses than those of the Turks

${ }^{68}$ This passage is quoted from Soudavar (2002, p. 100).

${ }^{69}$ Russian anthropologists explain that the South Siberian Mongoloid type "was formed as a result of the mixture of the numerically predominant Mongoloid Central Asiatic race with the ancient Europeoid population" (see Miklashevskaia 1968, p. 96). 
(Abu-1-Gazi 1958, p. 42 [text]; Ebülgazî 1975, pp. 57-58). According to Murav'yov (1977, p. 138), the Turkmens and the Uzbeks in Khiva did not intermix, seeing each other as distinct groups.

In sum, in terms of tribal and genetic compositions, as well as physiognomy, the Turkic nomads of the Mongol successor states in Central Asia and the Qipchaq Steppe were close or related to the 13th-century Mongols. Unlike the fragmented preMongol Turkic groups, the Turkic nomad elites of the Mongol successor states shared a common identity and historical consciousness. One should note that in numerous written (and oral) sources, the Timurids, the Moghuls, the Mughals, the Kazkahs, the Shibanid Uzbeks, and the Crimean Tatars depicted themselves as belonging to or descending from the Mongols. ${ }^{70}$ They also adopted and modified the Chinggisid Mongol dynastic and tribal genealogies first created by the Ilkhanid historians. Through these genealogies, they claimed descent from the ancient Mongols and such mythical figure as Alan Qo'a. ${ }^{71}$ Importantly, the historians of the Mongol successor states in Central Asia and the Qipchaq Steppe did not regard Afrāsiyāb as their progenitor. For instance, when the Moghul historian Muhammad Haidar Dughlat (2004, p. 418) relates that the rulers of Kashghar (the Qarakhanids) are "the

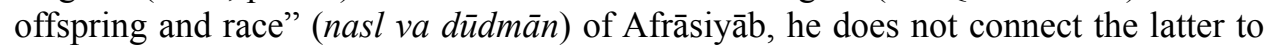
the Moghuls or the Timurids. As for Oghuz Khan, the Timurid and Uzbek historians regarded him as an ancestor of the Chinggisids and the Timurids. However, this claim to Oghuz descent was an expression of Muslim identity, not an Oghuz Turkic identity. Oghuz Khan was depicted as a descendant of Mongol Khan, that is, a Mongol in their genealogies. One should also note that the Timurids did not identify themselves with their contemporary Ottomans. For instance, Temür's grandson Ulugh Beg states in his Chinggisid history that Oghuz Khan, from whom the Ottoman dynasty descends, is not to be confused with his namesake from whom the Chinggisids and Timurids descend. ${ }^{72}$ Such a Mongol orientation of the Turkic nomads of the Mongol successor states in Central Asia and the Qipchaq Steppe ought to be understood as a natural reflection of their Mongol connection.

\section{Conclusion}

In this paper, I attempted to address the question, "Why did the Turkic nomads of the Mongol successor states in Central Asia and the Qipchaq Steppe retain a Mongol identity instead of reverting to pre-Mongol Turkic identities?" by refuting the widely held premise that "the minority Mongols" were assimilated by "the majority Turks".

\footnotetext{
${ }^{70}$ The Timurids, the Moghuls, the Mughals, and the Shibanid Uzbeks also had a Turkic identity. However, their Turkic identity was compatible with and encompassed the Mongol identity. On this point, see Lee (2016b, pp. 118-126).

${ }^{71}$ For more on this topic, see Lee (2016b, pp. 126-131).

${ }^{72}$ See Shajarat al-Atrāk (n.d., fols 61-62). For an abridged English translation, see Shajarat Ul Atrak (2007, pp. 40-41).
} 
The various Turkic groups of post-Kök Türk Central Asia and the Qipchaq Steppe did not form a single entity that shared a common past, patrilineal linages, royal tradition, and identity: They consisted of genetically heterogenous groups that did not share a common Kök Türk identity or genetic legacy. They also developed separate dynastic traditions such as the Oghuz and Afrāsiyāb traditions. Many groups did not even identify themselves as Türks. In other words, the "Turks" of pre-Mongol Central Asia and the Qipchaq Steppe formed a language family that shared a common nomadic culture, not a uniform majority that would later Turkicise the Mongols or that would be regarded as a common ancestral group by the Turkic nomads of the post-Mongol period.

The Turkic nomads of the Mongol successor states in Central Asia and the Qipchaq Steppe were closer to the 13th-century Mongols in terms of tribal and genetic affiliations than to the pre-Mongol Oghuz or Qipchaq Turkic groups. The Mongolic and Turkic tribes that had originated in Mongolia and those that were newly organised within the Chinggisid uluses formed their majority. Besides, their major Y-DNA haplogroup was haplogroup C2 like that of the Mongols. All in all, they were made up of the tribes and patrilineal lineages that were close or related to the Mongols, and the diverse nomadic groups that cannot be characterised as "the majority Turks". As a result, when the Turkic nomads of the Mongol successor states branched off into new group identities, such as the Chaghatays (Moghuls and Timurids), Kazakhs, Shibanid Uzbeks, Crimean Tatars, and Manghits/Noghays, among others, during the post-Mongol period, they retained a Mongol identity and various elements of Mongol tradition. Naturally, they were identified as Mongols or Tatars by Timurid, Uzbek, Crimean Tatar, and other pre-modern writers. ${ }^{73}$

We should then understand why such Turkic state-builders as Temür and $\mathrm{Mu}-$ hạmmad Shībānī Khan honoured the Mongol and Chinggisid dynastic traditions, not the pre-Mongol Turkic traditions. The Turkicisation of the Mongols in Central Asia and the Qipchaq Steppe was essentially a linguistic phenomenon, which did not accompany significant changes in genetic structure and identity.

\section{References}

Aboul-Ghazi Behadour Khan (1970): Histoire des Mongols et des Tatares. Trans. and ed. Petr I. Desmaisons. Amsterdam, Philo.

Abu-l-Gazi (1958): Rodoslovnaia turkmen: Sochinenie Abu-l-Gazi khana khivinskogo [The genealogy of the Turkmens: The work of Abu-1-Gazi, the khan of Khiva]. Trans. and ed. A.N. Kononov. Moscow-Leningrad, Izd-vo Akademii nauk SSSR.

Ando, Shiro (1992): Timuridische Emire nach dem Mu'izz al-ansāb: Untersuchung zur Stammesaristokratie Zentralasiens im 14. und 15. Jahrhundert. Berlin, Klaus Schwarz (Islamkundliche Untersuchungen 153).

${ }^{73}$ The use of the term Tatar by pre-modern European writers to refer to both the Mongols and the Turkic-speaking nomads of the Mongol successor states was therefore in line with such a practice. 
Balanovsky, O.-Zhabagin, M.-Agdzhoyan, A. et al. (2015): Deep Phylogenetic Analysis of Haplogroup G1 Provides Estimates of SNP and STR Mutation Rates on the Human Y Chromosome and Reveals Migrations of Iranic Speakers. PLoS One Vol. 10, No. 4: e0122968. doi.org/10.1371/journal.pone.0122968.

Balaresque, P.-Poulet, N.-Cussat-Blanc, S. et al. (2015): Y-Chromosome Descent Clusters and Male Differential Reproductive Success: Young Lineage Expansions Dominate Asian Pastoral Nomadic Populations. European Journal of Human Genetics Vol. 23, pp. 14131422. doi:10.1038/ejhg.2014.285.

Barthold, V. V. (1962): Four Studies on the History of Central Asia. Vol. 3, Mìr 'Alī-Shìr. A History of the Turkman People. Trans. and ed. V. Minorsky and T. Minorsky. Leiden, Brill.

Bartol'd, V. V. (1964): Ocherk istorii turkmenskogo naroda. In: Bregel, Yu. E. (ed.): Sochineniia. Vol. 2, Pt. 2. Moscow, Nauka.

de Beauplan, Guillaume Le Vasseur (1993): A Description of Ukraine. Guillaume Le Vasseur, Sieur de Beauplan. Trans. and ed. Andrew B. Pernal and Dennis F. Essar. Cambridge, Mass., Harvard University Press for the Harvard Ukrainian Research Institute.

Berkman, C. C. - Togan, İ. (2009): The Asian Contribution to the Turkish Population with Respect to the Balkans: Y-Chromosome Perspective. Discrete Applied Mathematics Vol. 157, No. 10, pp. 2341-2348. doi.org/10.1016/j.dam.2008.06.037.

Bernshtam, A. (1962): On the Origin of the Kirgiz People. In: Michael, H. N. (ed.): Studies in Siberian Ethnogenesis. Toronto, University of Toronto Press, pp. 119-143.

Bınbaş, İlker Evrım (2010): Ōguz Khan Narratives. In: Encyclopeedia Iranica. London-Boston, Routledge \& Kegan Paul. http://www.iranicaonline.org/articles/oguz-khan-narratives. (Accessed 10 October 2017.)

Carpini, John of Plano (1998): History of the Mongols. In: Dawson, Christopher (ed.): Mission to Asia. Toronto, University of Toronto Press, pp. 3-72.

Di Cristofaro, J.-Pennarun, E. - Mazieres, S. et al. (2013): Afghan Hindu Kush: Where Eurasian Sub-Continent Gene Flows Converge. PLoS One Vol. 8, No. 10: e76748. doi.org/10.1371/ journal.pone.0076748.

Crubézy, E.-Amory, S.-Keyser, C. et al. (2010): Human Evolution in Siberia: From Frozen Bodies to Ancient DNA. BMC Evolutionary Biology Vol. 10, No. 25: doi.org/10.1186/ 1471-2148-10-25.

Cui, Y.-Song, L. - Wei, D. et al. (2015): Identification of Kinship and Occupant Status in Mongolian Noble Burials of the Yuan Dynasty through a Multidisciplinary Approach. Philosophical Transactions of the Royal Society of London, series B, Biological Sciences Vol. 370, No. 1660: 20130378. doi: 10.1098/rstb.2013.0378.

Doğruyol, Harun (2012): Epic as a Literary Genre and the Turkish Epic "Oguz Khan". CBÜ Sosyal Bilimler Dergisi Vol. 10, No. 1, pp. 187-196.

Duan Chengshi 段成式 (n.d.): You yang za zu 西陽雜沮. [Miscellany of Youyang], Chapter 4. https://archive.org/stream/06047413.cn\#page/n120/mode/2up (Accessed 14 July 2017).

Dulik, M. C. - Osipova, L. P.-Schurr, T. G. (2011): Y-Chromosome Variation in Altaian Kazakhs Reveals a Common Paternal Gene Pool for Kazakhs and the Influence of Mongolian Expansions. PLoS One Vol. 6, No. 3: e17548. doi.org/10.1371/journal.pone.0017548.

Dulik, M. C.-Zhadanov, S. I. - Osipova, L. P. et al. (2012): Mitochondrial DNA and Y Chromosome Variation Provides Evidence for a Recent Common Ancestry between Native Americans and Indigenous Altaians. American Journal of Human Genetics Vol. 90, No. 2, pp. 229-246. doi: 10.1016/j.ajhg.2011.12.014.

Ebülgazî Bahadir Han (1975): Şecere-i Terākime. Istanbul, Tercüman. 
Elphinstone, Mountstuart (1842): An Account of the Kingdom of Caubul, and Its Dependencies, in Persia, Tartary, and India. London, Richard Bentley.

Fergus, Michael-Jandosova, Janar (2003): Kazakhstan: Coming of Age. London, Stacey International.

Finke, Peter (2014): Variations on Uzbek Identity: Strategic Choices, Cognitive Schemas and Political Constraints in Identification Processes. New York, Berghahn Books.

Fisher, A. (1978): The Crimean Tatars. Stanford, CA, Hoover Institution Press.

Frenkel, Yehoshua (2015): The Turkic Peoples in Medieval Arabic Writings. London, Routledge (Routledge Studies in the History of Iran and Turkey).

Golden, P. B. (1992): An Introduction to the History of the Turkic Peoples: Ethnogenesis and State Formation in Medieval and Early Modern Eurasia and the Middle East. Wiesbaden, Otto Harrassowitz.

Golden, Peter B. (2011): Central Asia in World History. Oxford, Oxford University Press.

Golden, Peter (2013): Courts and Court Culture in the Proto-urban and Urban Developments among the pre-Chinggisid Turkic Peoples. In: Durand-Guédy, David (ed.): Turko-Mongol Rulers, Cities and City Life. Leiden, Brill, pp. 21-73.

Golden, Peter B. (2015): The Turkic World in Maḥmûd al-Kâshgharî. In: Bemmann, J.Schmauder, M. (eds): Complexity of Interaction along the Eurasian Steppe Zone in the First Millennium CE. Bonn, Universität Bonn Inst. f. Vor- u. Frühgeschichtliche Archäologie (Bonn Contributions to Asian Archaeology 7), pp. 503-555.

Grugni, V.-Battaglia, V.-Hooshiar Kashani, B. et al. (2012): Ancient Migratory Events in the Middle East: New Clues from the Y-Chromosome Variation of Modern Iranians. PLoS One Vol. 7, No. 7: e41252. doi: 10.1371/journal.pone.0041252.

Gubina, M. A.-Damba, L. D. - Babenko, V. N. et al. (2013): Haplotype Diversity in MtDNA and Y-Chromosome in Populations of Altai-Sayan Region. Russian Journal of Genetics Vol. 49, No. 3, pp. 329-343. doi.org/10.1134/S1022795412120034.

Haber, M.-Platt, D. E.-Ashrafian Bonab, M. et al. (2012). Afghanistan's Ethnic Groups Share a Y-Chromosomal Heritage Structured by Historical Events. PLoS One Vol. 7, No. 3: e34288. doi.org/10.1371/journal.pone.0034288.

Ḥaidar Dughlat, Muhammad (2004): Tārīkh-i Rashīdī. Ed. 'Abbās Qulī Ghaffārī Fard. Tehran, Mīrās-i Maktūb.

Haydar Dughlat [Muhammad Haidar Dughlat] (1996): Tarikh-i-Rashidi: A History of the Khans of Moghulistan. Trans. and ed. W. M. Thackston, 2 vols. Cambridge, Mass., Department of Near Eastern Languages and Civilizations (Harvard University Sources of Oriental Languages and Literatures 37-38).

Herberstein, Sigmund (1963): Notes upon Russia: Being a Translation of the Earliest Account of that Country, Entitled Rerum Moscoviticarum Commentarii. Trans. and ed. R. H. Major. New York, Burt Franklin.

Ibn 'Arabshāh, Ahmad b. Muhammad (1936): Tamerlane, or Timur the Great Amir: From the Arabic Life by Ahmed Ibn Arabshah. Trans. J. H. Sanders. London, Luzac.

Ibn 'Arabshāh, Ahmad b. Muhammad (1986): 'Ajā'ib al-maqdūr fì nawā'ib Tìmūr. Ed. Ahmmad Fā'iz al-Ḥimșī. Beirut, Mu'assasat al-Risālah.

Ibn Khaldūn, 'Abd al-Raḥmān (1951): Al-Ta'rif bi-Ibn Khaldun wa-rịhlatihi Gharban wa-Sharqan. Ed. Muhammad ibn Tāwīt al-Ṭanjī. Cairo, Lajnat al-ta'līf wa-al-tarjamah wa-al-nashr.

İnalcık, H. (1977): Kırım hanlı̆̆ı. In: İslâm Ansiklopedisi, Vol. 6. İstanbul, Milli Eğitim Basımev, pp. $746-756$.

Ismagulov, O. (1968): The Process of Formation of the Kazakh Type in Relation to Their Ethnogenesis. In: Field, Henry (ed.): Contributions to the Physical Anthropology of Central 
Asia and the Caucasus. Trans. Barbara Heath. Cambridge, Mass., Peabody Museum, pp. $129-132$.

ISOGG (International Society of Genetic Genealogy) (2018): Y-DNA Haplogroup Tree 2018. http://www.isogg.org/tree (Accessed 26 January 2018).

Juvaynī, 'Alā' al-Dīn 'Ațā Malik (1958): The History of the World-Conqueror. Trans. and ed. J. A. Boyle. Cambridge, Mass., Harvard University Press.

Kafesoğlu, İbrahim (1972): Selçuklu Tarihi. Istanbul, Milli Eğitim Basımevi.

Al-Kāšğarī, Mạ̣mūd (1982-1985): Compendium of the Turkic Dialects (Dīwān Luḡāt at-Turk). Trans. and ed. Robert Dankoff, in collaboration with James Kelly, 3 pts. Cambridge, Mass., Department of Near Eastern Languages and Civilizations, Harvard University.

Katoh, T. - Munkhbat, B. - Tounai, K. et al. (2005): Genetic Features of Mongolian Ethnic Groups Revealed by Y-Chromosomal Analysis. Gene Vol. 346, pp. 63-70. DOI: 10.1016/j.gene. 2004.10.023.

Keyser, C. - Bouakaze, C. - Crubézy, E. et al. (2009): Ancient DNA Provides New Insights into the History of South Siberian Kurgan People. Human Genetics Vol. 126, No. 3, pp. 395-410. doi: 10.1007/s00439-009-0683-0.

Kharkov, V. N. - Khamina, K. V.-Medvedeva, O. F. et al. (2013): Gene Pool Structure of Tuvinians Inferred from Y-Chromosome Marker Data. Genetika Vol. 49, No. 12, pp. 1236-1244.

Kharkov, V. N.-Khamina, K. V.-Medvedeva, O. F. et al. (2014): Gene Pool of Buryats: Clinal Variability and Territorial Subdivision Based on Data of Y-Chromosome Markers. Russian Journal of Genetics Vol. 50, No. 2, pp. 180-190. doi.org/10.1134/S1022795413110082.

Khunj̄ị, Fażlallāh b. Rūzbihān [Isfahānī] (1341/1962): Mihmān-nāma-i Bukhārāa: Tārīkh-i pādshāhī-i Muhammad Shībānī. Ed. Manūchihr Sutūda. Tehran, Bungāh-i Tarjuma va Nashr-i Kitāb.

Klyashtornyi, S. G. - Sultanov, T. I. (2000): Gosudarstva i narody Evraziyskikh stepey: Drevnost' $i$ srednevekov'ye. St. Petersburg, Peterburgskoye Vostokovedenie.

Lee, Joo-Yup (2016a): Qazaqliq, or Ambitious Brigandage, and the Formation of the Qazaqs: State and Identity in Post-Mongol Central Eurasia. Leiden, Brill.

Lee, Joo-Yup (2016b): The Historical Meaning of the Term Turk and the Nature of the Turkic Identity of the Chinggisid and Timurid Elites in Post-Mongol Central Asia. Central Asiatic Journal Vol. 59, pp. 101-132.

Lee, Joo-Yup - Kuang, Shuntu (2017): A Comparative Analysis of Chinese Historical Sources and Y-DNA Studies with Regard to the Early and Medieval Turkic Peoples. Inner Asia Vol. 19, No. 2, pp. 197-239.

Li, Chunxiang et al. (2010): Evidence That a West-East Admixed Population Lived in the Tarim Basin as Early as the Early Bronze Age. BMC Biology Vol. 8, No. 15, pp. 9-10. doi: $10.1186 / 1741-7007-8-15$.

Linghu Defen 令狐德芬 (2003): Zhoushu 周書 [Book of the Zhou Dynasty]. Beijing, Zhonghua shuju.

Liu Xu 劉昫 (2002): Jiu Tangshu 舊唐書 [Old book of the Tang Dynasty]. Beijing, Zhonghua shuju.

MacGahan, Januarius A. (1970): Campaigning on the Oxus, and the Fall of Khiva. New York, Arno Press.

Mano, Eiji (1978): Moghūlistān. Acta Asiatica: Bulletin of the Institute of Eastern Culture Vol. 34, pp. $46-60$.

Manz, Beatrice F. (1989): The Rise and Rule of Tamerlane. Cambridge, Mass., Cambridge University Press. 
Manz, Beatrice F. (1994): Historical Background. In: Manz, Beatrice F. (ed.): Central Asia in Historical Perspective. Boulder, CO, Westview, pp. 4-24.

Manz, Beatrice F. (2009): Temür and the Early Timurids to c. 1450. In: The Cambridge History of Inner Asia: The Chinggisid Age, edited by Nicola Di Cosmo-Allen J. Frank-Peter B. Golden. Cambridge, Mass., Cambridge University Press, pp. 182-198.

Manz, Beatrice F. (2016): The Empire of Tamerlane as an Adaptation of the Mongol Empire: An Answer to David Morgan, "The Empire of Tamerlane: An Unsuccessful Re-Run of the Mongol State?" Journal of the Royal Asiatic Society Vol. 26, Nos 1-2, pp. 281-291.

Mecit, Songül (2014): The Rum Seljuqs: Evolution of a Dynasty. Abingdon, Routledge.

Miklashevskaia, N. N. (1968): Somatological Investigation in Kirghizia. In: Field, Henry (ed.): Contributions to the Physical Anthropology of Central Asia and the Caucasus. Trans. Barbara Heath. Cambridge, Mass., Peabody Museum, pp. 85-96.

Moriyasu, T. - Suzuki, K. - Saito, S.-Tamura, T. - Yudong, Bai (2009): Shineusu hibun yakuchu [Šine-Usu inscription from the Uighur period in Mongolia: revised text, translation and commentaries]. Nairiku Ajia gengo no kenkyu [Studies on the Inner Asian Languages] Vol. 24, pp. 1-92.

Mu 'izz al-ansāb fì shajarat al-ansāb (2006). Trans. and ed. Abuseitova, M. Kh. et al. Almaty, Dayk (Istoriya Kazakhstana v persidskikh istochnikakh 3).

Murav'yov, Nikolay (1977): Journey to Khiva: Through the Turkoman Country. London, Oguz.

Oshanin, L. V. (1964): Anthropological Composition of the Population of Central Asia, and the Ethnogenesis of its Peoples. 2 vols. Trans. V. M. Maurin, ed. H. Field. Cambridge, Mass., Peabody Museum of Archaeology.

Otsuka, Osamu (2007): Kinikushizoku to afurāsuiyābu: Perushiago fuhenshi jujutsu no tenkai to serujūkuchō no kigen [The Qiniq and Afrāsiyāb: The development of the Persian universal histories and the origin of the Seljuqs]. Oriento Vol. 50, No. 1, pp. 83-84.

Ouyang Xiu 歐陽修-Qi, Song 宋阥 (2003): Xin Tangshu 新唐書 [New book of the Tang Dynasty]. Beijing, Zhonghua shuju.

Pakendorf, B.-Novgorodov, I. N.-Osakovskij, V. L.-Stoneking, M. (2007): Mating Patterns amongst Siberian Reindeer Herders: Inferences from MtDNA and Y-Chromosomal Analyses. American Journal of Physical Anthropology Vol. 133, No. 3, pp. 1013-1027.

Peacock, A. C. S. (2010): Early Seljuq History: A New Interpretation. New York, NY, Routledge.

Qïrïmī, 'Abd al-Ghaffār (1343/1924-1925): Umdet ül-tevarikh. Ed. Najīb 'Āsim, supplement to Türk Tarih Encümeni Mecmuasi. Istanbul.

Rashīd al-Dīn Fażlallāh Hamadānī (1988): Jāmi al-tavārīkh. Ed. B. Karīmī. Tehran, Intishārāt-i Iqbāl.

Rashiduddin Fazlullah [Rashīd al-Dīn Fażlullāh Hamadānī] (1998-1999): Jami ‘u't-tawarikh (Compendium of Chronicles): A History of the Mongols. Trans. W. M. Thackston, 3 pts. Cambridge, Mass., Department of Near Eastern Languages and Civilizations, Harvard University.

Sabitov, Z. (2013): Etnogenez kazakhov s tochki zreniya populyatsionnoy genetiki [The ethnogenesis of the Kazakhs from the perspective of population genetics]. Russian Journal of Genetic Genealogy Vol. 5, No. 1, pp. 29-47.

Safi, Omid (2006): The Politics of Knowledge in Premodern Islam. Chapel Hill, University of North Carolina.

Scott, Charles Henry (1854): The Baltic, the Black Sea, and the Crimea: Comprising Travels in Russia, a Voyage Down the Volga to Astrachan, and a Tour Through Crim Tartary. London, Richard Bentley. 
Sela, Ron (2013): Revisiting the Origin Myths of the Turks. Central Asia in a Historical Context (blog). https://rsela.wordpress.com/2013/04/24/revisiting-the-origin-myths-of-the-turks/ (Accessed 10 October 2017).

Semino, O.-Passarino, G.-Oefner, P. J. et al. (2000): The Genetic Legacy of Paleolithic Homo Sapiens Sapiens in Extant Europeans: A Y Chromosome Perspective. Science Vol. 290, pp. $1155-1159$.

Sengupta, Sanghamitra et al. (2006): Polarity and Temporality of High-Resolution Y-Chromosome Distributions in India Identify Both Indigenous and Exogenous Expansions and Reveal Minor Genetic Influence of Central Asian Pastoralists. The American Journal of Human Genetics Vol. 78, No. 2, pp. 202-221.

Shajarat al-Atrāk, MS, London, British Library, India Office, Ethé 172.

Shajarat Ul Atrak: Or Genealogical Tree of the Turks and Tatars (2007). Trans. William Miles. London, Kessinger Publishing.

Shi, H. - Qi, X. - Zhong, H. et al. (2013): Genetic Evidence of an East Asian Origin and Paleolithic Northward Migration of Y-Chromosome Haplogroup N. PLoS One Vol. 8, No. 6. e66102. doi.org/10.1371/journal.pone.0066102.

Silay, K. (ed.) (1966): An Anthology of Turkish Literature. Bloomington, Ind., Indiana University Press.

Sinor, D. (1982). The Legendary Origin of the Turks. In: Zygas, E. V.-Voorheis, P. (eds): Folklorica: Festschrift for Felix J. Oinas. Bloomington, Ind., Indiana University Press (Indiana University Uralic and Altaic Series 141), pp. 223-257.

Sinor, D. (1985): Some Components of the Civilization of the Turks (6th to 8th Century A.D.). In: Jarring, Gunna-Rosén, Steffan (eds): Altaistic Studies. Papers Presented at the 25th Meeting of the Permanent International Altaistic Conference at Uppsala June 7-11, 1982. Stockholm, Almqvist \& Wiksell, pp. 152-157.

Skhalyakho, R. A.-Zhabagin, M.-Yusupov, Y. M.-Balanovska, E. (2016): Genofond turkmen karakalpakstana $\mathrm{v}$ kontekste populyatsiy tsentralnoy azii (polimorfizm y-khromosomy) [Gene pool of Turkmens from Karakalpakstan in their Central Asian context (Ychromosome polymorphism)]. Antropologiya Vol. 3, pp. 86-96.

Song Lian 宋濂 (2005): Yuanshi 元史 [History of the Yuan Dynasty]. Beijing, Zhonghua shuju.

Soudavar, Abolala (2002): The Early Safavids and Their Cultural Interactions with Surrounding States. In: Keddie, Nikki R.-Matthee, Rudi (eds): Iran and the Surrounding World: Interactions in Culture and Cultural Politics. Seattle, University of Washington Press, pp. $89-120$.

Sultanov, T. I. (1982): Kochevyye plemena Priaral'ya $v$ XV-XVII vv. (Voprosy etnicheskoy $i$ sotsial'noy istorii). Moscow, Nauka.

Tambets, K. - Rootsi, S. - Kivisild, T. et al. (2004): The Western and Eastern Roots of the Saamithe Story of Genetic "Outliers" Told by Mitochondrial DNA and Y Chromosomes. American Journal of Human Genetics Vol. 74, No. 4, pp. 661-682.

Tao Zongyi 陶宗儀 (1959): Nancun Chuogeng lu 南村輟耕錄 [Nancun's records taken while stopping from field work]. Beijing, Zhonghua shu ju.

Tekin, T. (1983): The Tariat (Terkhin) inscription. $A O H$ Vol. 37, No. 1, pp. 43-68.

Tokarev, S. A. (1962): On the Origin of the Buryat Nation. In: Michael, H. N. (ed.): Studies in Siberian Ethnogenesis. Toronto, University of Toronto Press, pp. 102-118.

Vámbéry, Arminius (1865): Travels in Central Asia: Being the Account of a Journey from Teheran across the Turkoman Desert on the Eastern Shore of the Caspian to Khiva, Bokhara,and Samarcand Performed in the Year 1863. New York, Harper \& Brothers. 
Vásáry, István (2015): Two Patterns of Acculturation to Islam: The Qarakhanids versus the Ghaznavids and Seljuqs. In: Herzig, Edmund-Stewart, Sarah (eds): The Age of the Seljuqs. London, I. B. Tauris (The Idea of Iran 6), pp. 9-28.

Wei Zheng 魏徵 (2008): Suishu 隋書 [Book of the Sui Dynasty]. Beijing, Zhonghua shuju.

Wells, R. S. - Yuldasheva, N. - Ruzibakiev, R. et al. (2001): The Eurasian Heartland: A Continental Perspective on Y-Chromosome Diversity. PNAS Vol. 98, No. 18, pp. 10244-10249.

$\mathrm{Xu}$, Dan-Wen, Shaoqing (2017): The Silk Road: Language and Population Admixture and Replacement. In: Xu, Dan-Li, Hui (eds): Languages and Genes in Northwestern China and Adjacent Regions. Singapore, Springer, pp. 55-78.

Xue, Y.-Zerjal, T.-Bao, W. et al. (2005): Male Demography in East Asia: A North-South Contrast in Human Population Expansion Times. Genetics Vol. 172, No. 4, pp. 24312439.

Y Chromosome Consortium (2002): A Nomenclature System for the Tree of Human Y-Chromosomal Binary Haplogroups. Genome Research Vol. 12, No. 2, pp. 339-348.

Yu Ji 盧集 (1965): Gaochang wang shi xun bei 高昌王世勳碑 [The monumental inscription of the king of Gaochang]. In: Su, Tianjue 蘇天爵 (ed.): Guo chao wen lei 國朝文類. Taipei, Taiwan shang wu yin shu guan. Vol. 2, pp. 259-270.

Yudin, V. P. (2001): O rodoplemennom sostave mogulov Mogulistana i Mogulii i ikh etnicheskikh svyazyakh s kazakhskim i drugimi sosednimi narodami. In: Baranova, Yu. G. (ed.): Tsentral'naya Aziya v XIV-XVIII vekakh glazami vostokoveda. Almaty, Dayk, pp. 72-95.

Yūsuf Khāṣs Hājib (1983): Wisdom of Royal Glory: A Turko-Islamic Mirror for Princes. Trans. Robert Dankoff. Chicago, University of Chicago Press.

Zerjal, T.-Wells, R. S.-Yuldasheva, N.-Ruzibakiev, R.-Tyler-Smith, C. (2002): A Genetic Landscape Reshaped by Recent Events: Y-Chromosomal Insights into Central Asia. The American Journal of Human Genetics Vol. 71, No. 3, pp. 466-482.

Zhabagin, Maxat-Balanovska, Elena-Sabitov, Zhaxylyk et al. (2017): The Connection of the Genetic, Cultural and Geographic Landscapes of Transoxiana. Scientific Reports Vol. 7, No. 3085 , pp. $1-11$.

Zhivkov, Boris (2013): Khazaria in the Ninth and Tenth Centuries. Trans. Daria Manova. Leiden, Brill.

Zhong, H.-Shi, H.-Qi, X. B. et al. (2010): Global Distribution of Y-Chromosome Haplogroup C Reveals the Prehistoric Migration Routes of African Exodus and Early Settlement in East Asia. Journal of Human Genetics Vol. 55, No. 7, pp. 428-435.

Zhou, R. - Yang, D. - Zhang, H. et al. (2008): Origin and Evolution of Two Yugur Sub-Clans in Northwest China: A Case Study in Paternal Genetic Landscape. Annals of Human Biology Vol. 35, No. 2, pp. 198-211. 